\title{
Peramalan Jumlah Kunjungan Wisatawan Menggunakan Triple Exponential Smoothing
}

\author{
I Wayan Agus Surya Darma ${ }^{1}$, I Putu Eka Giri Gunawan², Ni Putu Sutramiani ${ }^{3}$ \\ 1,2Program Studi Teknik Informatika, STMIK STIKOM Indonesia \\ Denpasar, Bali, Indonesia, 80225, Telp. (0361) 256995 \\ ${ }^{3}$ Program Studi Teknologi Informasi, Fakultas Teknik, Universitas Udayana \\ Bukit Jimbaran, Bali, Indonesia, 80361, telp. (0361) 701806 \\ e-mail: surya@stiki-indonesia.ac.id, eka.giri@stiki-indonesia.ac.id, sutramiani@unud.ac.id
}

\begin{abstract}
Abstrak
Bali merupakan salah satu destinasi pariwisata terbaik di dunia. Berdasarkan berita resmi statistik yang dipublikasikan oleh Badan Pusat Statistik Bali, jumlah kunjungan wisatawan mancanegara ke Bali pada bulan Juni 2019 mencapai 549.751 kunjungan. Peramalan kunjungan wisatawan merupakan faktor yang sangat penting untuk menentukan kebijakan tempat tujuan wisata, meminimalkan ketidakpastian dan resiko investasi. Hal ini merupakan hal yang sangat penting karena sektor pariwisata merupakan tulang punggung ekonomi di Bali. Penelitian ini mengangkat topik bagaimana mengimplementasikan metode Triple Exponential Smoothing pada proses peralaman jumlah wisatawan. Kami menggunakan data historis kunjungan wisatawan ke Bali yang diperoleh dari Badan Pusat Statistik Provinsi Bali. Hasil peramalan dievaluasi menggunakan mean absolute error untuk menunjukan rata-rata kesalahan dalam perhitungan peramalan. Rata-rata Mean Absolute Error yang dihasilkan pada peramalan ini adalah 18 dengan hasil evaluasi terbaik dengan menggunakan Alpha 0.9, Beta 0 dan Gamma 0.8.
\end{abstract}

Kata Kunci: Kunjungan Wisatawan, Mean Absolute Error, Peramalan, Triple Exponential Smoothing.

\begin{abstract}
Bali is one of the best tourism destinations in the world. Based on official statistical news published by Badan Pusat Statistik Provinsi Bali, the number of foreign tourist visits to Bali in June 2019 reached 549,751. Forecasting tourist visits is a very important factor in determining tourist destination policies, minimizing uncertainty and investment risk. This is very important because the tourism sector is the backbone of the economy in Bali. This research raises the topic of how to implement the Triple Exponential Smoothing method in forecasting the number of tourists visits. We use historical data on tourist visits to Bali obtained from the Badan Pusat Statistik Provinsi Bali from January 2011 to July 2019. Forecasting results are evaluated using mean absolute error to show the average error in forecasting calculations. Based on the results, the average Mean Absolute Error generated in this forecast is 18 with the best evaluation results using Alpha 0.9, Beta 0, and Gamma 0.8.
\end{abstract}

Keywords: Tourist Visits, Mean Absolute Error, Forecasting, Triple Exponential Smoothing.

\section{Pendahuluan}

Bali merupakan salah satu destinasi pariwisata terbaik di dunia. Berdasarkan berita resmi statistik yang dipublikasikan oleh Badan Pusat Statistik Bali, kunjungan wisatawan mancanegara ke Bali pada bulan Juni 2019 mencapai 549.751 kunjungan. Peramalan kunjungan wisatawan merupakan faktor yang sangat penting untuk menentukan kebijakan tempat tujuan wisata, meminimalkan ketidakpastian dan resiko investasi. Hal ini merupakan hal 

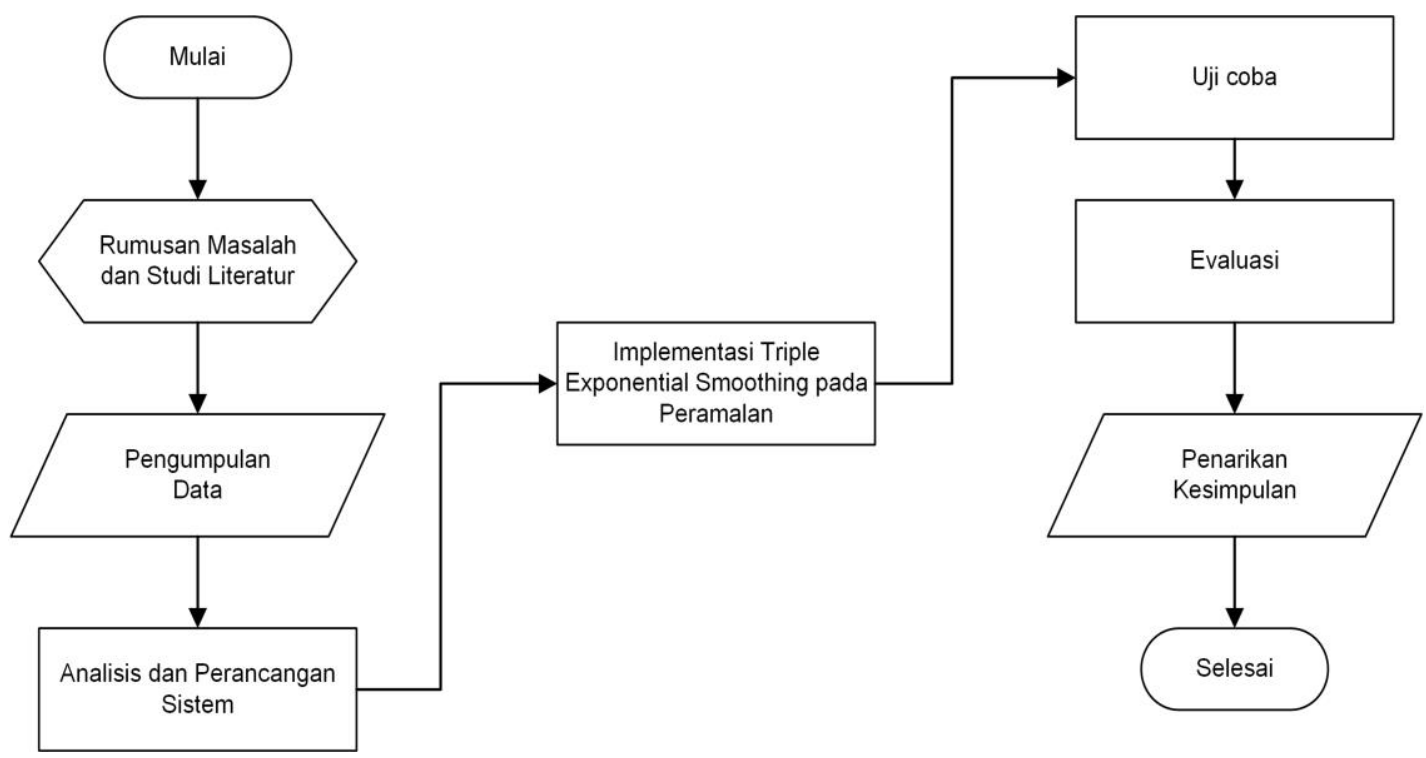

Gambar 1. Metodologi Penelitian

yang sangat penting karena sektor pariwisata merupakan salah satu tulang punggung perekonomian di Bali.

Penelitian terkait peramalan pernah dilakukan menggunakan metode Triple Exponential Smoothing pada peramalan peramalan jumlah mahasiswa baru [1], peramalan jumlah penumpang [2], prediksi keuntungan bisnis [3] dan peramalan penjualan souvenir [4], peramalan penjualan obat [5], dan prediksi kebutuhan bahan baku pupuk [6]. Metode Triple Exponential Smoothing dapat memberikan hasil peramalan berdasarkan data yang bersifat musiman. Peramalan dapat dimanfaatkan dalam berbagai bidang untuk pengambilan keputusan. Peramalan pernah dilakukan untuk memprediksi partisipasi pemilih dalam pemilu presiden 2014 menggunakan Support Vector Machine. Penelitian ini menghasilkan akurasi tertinggi yang didapat dalam memprediksi partisipasi pemilih sebesar $97.50 \%$ [7]. Pada kasus peramalan jumlah tersangka penyalahgunaan narkoba, peramalan dilakukan dengan menerapkan metode Multilayer Perceptron yang dapat memprediksi penurunan jumlah penyalahgunaan narkoba pada tahun 2019 [8]. Peramalan juga diterapkan dalam peramalan watak dan perjodohan berdasarkan wariga Bali menggunakan metode Fuzzy Logic [9]. Penelitian terkait juga pernah dilakukan dengan berbagai metode seperti meramal kunjungan wisatawan di objek wisata Bedugul menggunakan Fuzzy Time Series [10], peramalan jumlah wisatawan mancanegara di kota Pontianak menggunakan metode Deseasonalized [11], peramalan dengan menerapkan ARIMA pada jumlah penumpang pesawat [12], kereta api [13], peramalan menggunakan metode Trend Moment pada penjualan furniture [14] dan peramalan jumlah persediaan minuman menggunakan metode Moving Average [15]. Penelitian lainnya pernah mengusulkan kombinasi metode fuzzy Logic dan algoritma Cuckoo Search untuk peramalan beban listrik [16] dan Random Forest untuk meramalkan kandidat siswa baru [17].

Hasil penelitian ini merupakan implementasi metode Triple Exponential Smoothing pada peralaman kunjungan wisatawan. Kami menggunakan data kunjungan wisatawan ke Bali pada rentang waktu bulan Januari 2011 sampai dengan Juni 2019 yang diperoleh dari Badan Pusat Statistik Provinsi Bali. Artikel ini disusun sebagai berikut, bagian 1 menyajikan latar belakang dan penelitian terkait. Bagian 2 menyajikan metodologi penelitian. Bagian 3 menyajikan uji coba dan analisis hasil pada penelitian ini. Bagian 4 Menyajikan kesimpulan dan penelitian berikutnya pada artikel ini.

\section{Metodologi Penelitian}

Tahapan-tahapan penelitian yang dilakukan pada penelitian ini dijabarkan dalam alur penelitian yang ditunjukkan pada Gambar 1 yang menjelaskan tahapan-tahapan penelitian yang dimulai dengan perumusan masalah dan studi literatur mengenai peralaman kunjungan wisatawan. Langkah kedua adalah pengumpulan data kunjungan wisatawan. Kami 


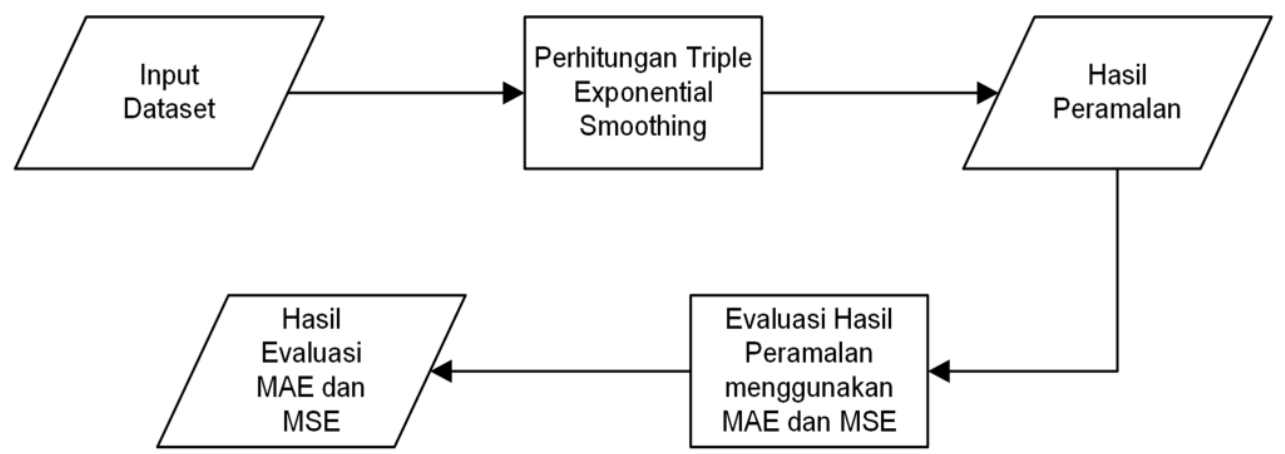

Gambar 2. Gambaran umum peramalan menggunakan Triple Exponential Smoothing

mengumpulkan data wisatawan yang bersumber dari Badan Pusat Statistik Provinsi Bali dengan rentang waktu kunjungan wisatawan Januari 2011 sampai dengan Juni 2019. Langkah ketiga yaitu menganalisis dan merancang sistem peramalan dengan menggunakan metode Triple Exponential Smoothing. Langkah keempat yaitu mengimplementasikan sistem berdasarkan analisis dan perancangan dengan menggunakan data kunjungan wisatawan untuk diproses menggunakan metode Triple Exponential Smoothing untuk mendapatkan hasil peramalan. Langkah kelima yaitu melakukan uji coba untuk mengetahui tingkat keberhasilan sistem. Langkah keenam yaitu mengevaluasi hasil peramalan dengan melakukan uji coba menggunakan Mean Absolute Error (MAE) dan Mean Squared Error (MSE) untuk menunjukan rata-rata kesalahan dalam perhitungan peramalan. Langkah terakhir adalah penarikan kesimpulan berdasarkan hasil pengujian yang telah dilakukan. Berikut ini adalah gambaran umum peramalan menggunakan Triple Exponential Smoothing yang ditunjukkan pada Gambar 2.

\subsection{Input Dataset}

Kami menggunakan data kunjungan wisatawan ke Bali yang diperoleh dari Badan Pusat Statistik Provinsi Bali. Data kunjungan ini terdiri dari data time series dengan rentang waktu Januari 2011 sampai dengan Juni 2019. Data ini berdasarkan kunjungan wisatawan ke Bali yang dirangkum berdasarkan total jumlah kunjungan perbulan.

\subsection{Perhitungan Peramalan Menggunakan Triple Exponential Smoothing}

Hasil peramalan merupakan prediksi jumlah kunjungan berdasarkan data kunjungan historis yang telah dihitung menggunakan metode Triple Exponential Smoothing. Hasil peramalan akan membandingkan data aktual kunjungan wisatawan dan hasil perhitungan dari Triple Exponential Smoothing.

Triple Exponential Smoothing merupakan metode peramalan yang memiliki kemampuan untuk menangani faktor musiman dan faktor kecenderungan yang muncul secara bersamaan pada sebuah data time series. Triple Exponential Smoothing terdiri atas tiga unsur yaitu unsur pemulusan, unsur trend dan musiman untuk setiap periode dengan menggunakan tiga pembobotan dalam proses peramalan. Tiga bobot ini adalah alpha $(\alpha)$, beta $(\beta)$, dan gamma $(\mathrm{Y})$. Bobot alpha $(\alpha)$ adalah parameter yang digunakan untuk mengontrol penghalusan relatif pada pengamatan yang baru dilakukan. Bobot beta $(\beta)$ adalah parameter yang digunakan untuk mengontrol penghalusan relatif untuk mengestimasi kemunculan unsur kecenderungan pada proses peramalan. Bobot beta memiliki nilai dari 0 hingga 1 . Bobot gamma adalah sebuah parameter yang digunakan untuk mengontrol penghalusan relatif untuk mengestimasi kemunculan unsur musiman. Gamma memiliki nilai dari 0 hingga 1.

Triple Exponential Smoothing memiliki tiga parameter yaitu proses pemulusan $\left(A_{t}\right)$, proses estimasi trend $\left(T_{t}\right)$, dan proses estimasi musiman $\left(\hat{Y}_{t+p}\right)$. Berikut ini adalah persamaan dasar untuk tiga parameter winter dan peramalannya.

$$
A_{t}=\alpha \frac{Y_{t}}{S_{t-L}}+(1-\alpha)\left(A_{t-1}+T_{t-1}\right)
$$




$$
\begin{aligned}
& T_{t}=\beta\left(A_{t}-A_{t-1}\right)+(1-\beta) T_{t-1} \\
& S_{t}=\gamma \frac{Y_{t}}{A_{t}}+(1-\gamma) S_{t-L}
\end{aligned}
$$

Proses peramalan kunjungan wisatawan menggunakan Persamaan 1 sampai dengan 3 untuk proses pemulusan dan estimasi trend pada metode Tripe Exponential Smoothing. Variabel $L$ merupakan panjangnya musim, yaitu panjangnya tahun data kunjungan wisatawan yang digunakan pada proses peramalan dan $S_{t}$ merupakan estimasi musiman ke -t. Persamaan untuk menghitung nilai peramalan menggunakan persamaan 4 berikut ini.

$$
\hat{Y}_{t+p}=\left(A_{t}+T_{t} \rho\right) S_{t-L+p}
$$

Variabel A dapat bernilai sama dengan nilai data aktual pertama, yaitu jumlah kunjungan wisatawan aktual pada bulan awal tahun pertama. Variabel $\mathrm{T}$ memiliki nilai 0 karena nilai trend didapatkan dari periode sebelumnya yang tidak ada. Variabel $S$ diasumsikan bernilai 1 untuk menghilangkan pengaruh musiman pada data aktual. Hasil peramalan berupa data prediksi jumlah kunjungan wisatawan pada bulan berikutnya yang disajikan dalam bentuk grafik.

\subsection{Evaluasi Hasil Peramalan Menggunakan MAE dan MSE}

Hasil evaluasi peramalan menggunakan Mean Absolute Error (MAE) dan Mean Squared Error (MSE) untuk mengukur keberhasilan metode Triple Exponential Smoothing dalam memprediksi jumlah kunjungan wisatawan.

Pada proses peramalan, pengaruh ketidakpastian diminimumkan untuk mengurangi kesalahan prediksi (forecast error). Kami mengukur Forecast Error dengan menggunakan Mean Absolute Error (MAE) yaitu rata-rata nilai Absolute Error dari kesalahan meramal dan Mean Squared Error (MSE), dengan formula sebagai berikut:

$$
\begin{aligned}
& M A E=\frac{\sum\left|Y_{t}-\hat{Y}_{t}\right|}{\mathrm{n}} \\
& M S E=\frac{\sum\left|Y_{t}-\hat{Y}_{t}\right|^{2}}{\mathrm{n}}
\end{aligned}
$$

Persamaan 5 dan Persamaan 6 digunakan untuk mengevaluasi hasil peramalan pada Triple Exponential Smoothing. $Y_{\mathrm{t}}$ merupakan data aktual yang digunakan pada proses perhitungan berdasarkan dataset yang digunakan dalam waktu t. $\hat{Y}_{t}$ merupakan data ramalan dihitung dari model yang digunakan dalam waktu $t$ dan $n$ merupakan total jumlah data.

\section{Hasil dan Pembahasan}

Bagian ini membahas tentang uji coba dan hasil implementasi Triple Exponential Smoothing pada peramalan kunjungan wisatawan. Berikut ini adalah tahapan-tahapan pada bagian ini.

\subsection{Persiapan data}

Kami menggunakan data kunjungan wisatawan ke Bali pada rentang waktu bulan Januari 2011 sampai dengan Juni 2019 yang diperoleh dari Badan Pusat Statistik Provinsi Bali. Sampel data kunjungan wisatawa ditunjukkan pada Tabel 1.

\subsection{Implementasi Triple Exponential Smoothing}

Proses peramalan pada sistem ini menggunakan metode Triple Exponential Smoothing. Hasil peramalan ditampilkan dalam dashboard yang menampilkan informasi hasil peramalan yang telah dilakukan berdasarkan data kunjungan wisatawan yang diujikan. Hasil peramalan disajikan dalam bentuk grafik hasil peramalan berdasarkan data aktual dan data hasil peramalan menggunakan Triple Exponential Smoothing. Grafik hasil peramalan disajikan berdasarkan rentang waktu data kunjungan wisatawan. Selain informasi berupa grafik, 
Tabel 1. Sampel data kunjungan wisatawan ke Bali pada Januari 2018-Juni 2019

\begin{tabular}{lcc}
\hline \multicolumn{1}{c}{ Bulan } & Tahun & Jumlah Kunjungan \\
\hline Januari & 2018 & 358,065 \\
Februari & 2018 & 452,423 \\
Maret & 2018 & 492,678 \\
April & 2018 & 516,777 \\
Mei & 2018 & 528,512 \\
Juni & 2018 & 544,550 \\
Juli & 2018 & 624,366 \\
Agustus & 2018 & 573,766 \\
September & 2018 & 555,903 \\
Oktober & 2018 & 517,889 \\
Nopember & 2018 & 406,725 \\
Desember & 2018 & 498,819 \\
Januari & 2019 & 456,218 \\
Februari & 2019 & 437,537 \\
Maret & 2019 & 449,637 \\
April & 2019 & 476,327 \\
Mei & 2019 & 485,795 \\
Juni & 2019 & 549,751
\end{tabular}

halaman dashboard juga menampilkan nilai mean absolute error, mean squared error dan root mean squared error yang dihasilkan berdasarkan perhitungan Triple Exponential Smoothing.

Kode Program 1 merupakan kode program yang digunakan untuk melakukan proses peramalan menggunakan Triple Exponential Smoothing. Kami menggunakan dataset kunjungan wisatawan ke Bali pada rentang Januari 2011 sampai dengan Juli 2019 untuk menghitung peramalan kunjungan wisatawan menggunakan metode Triple Exponential Smoothing.

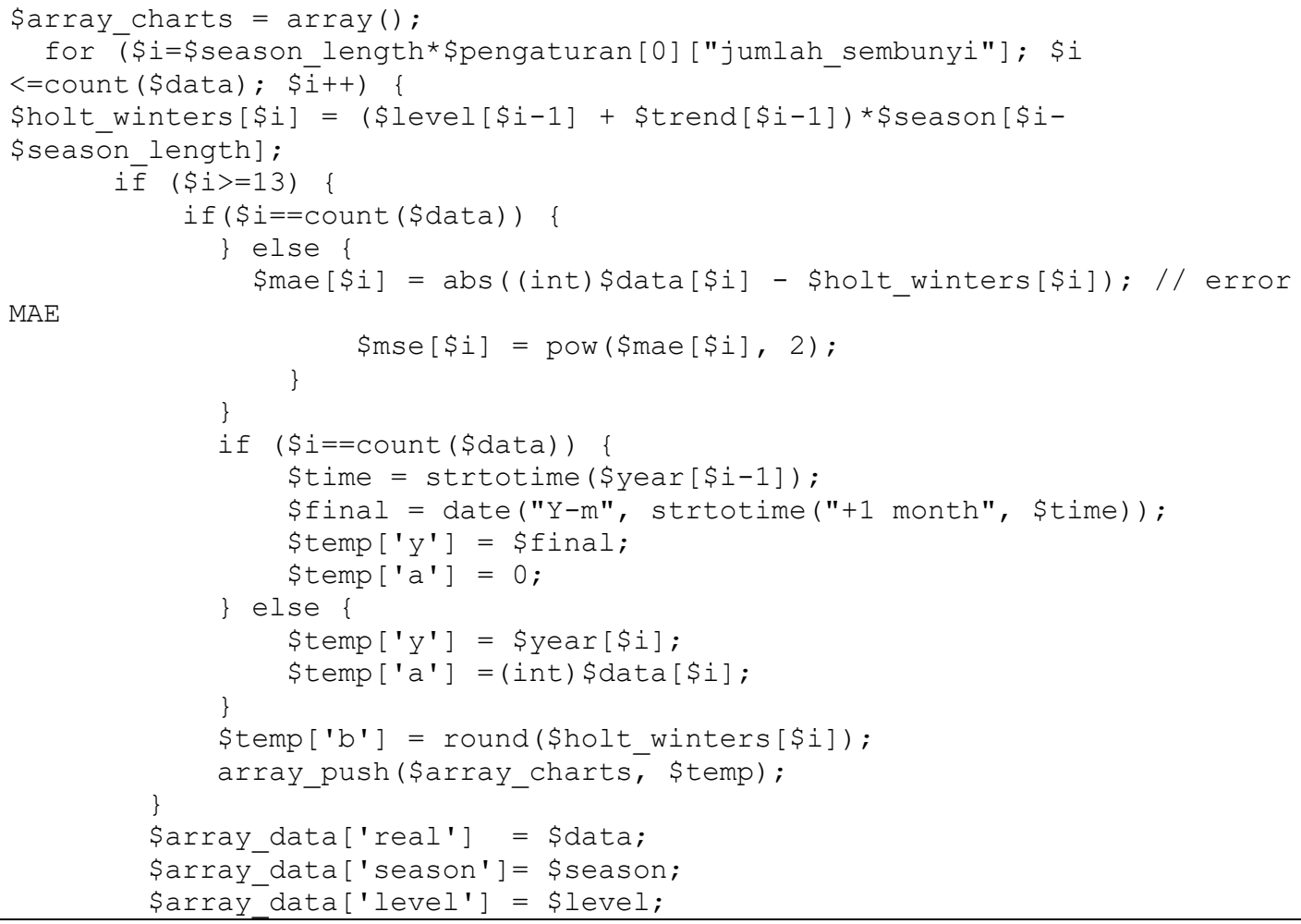




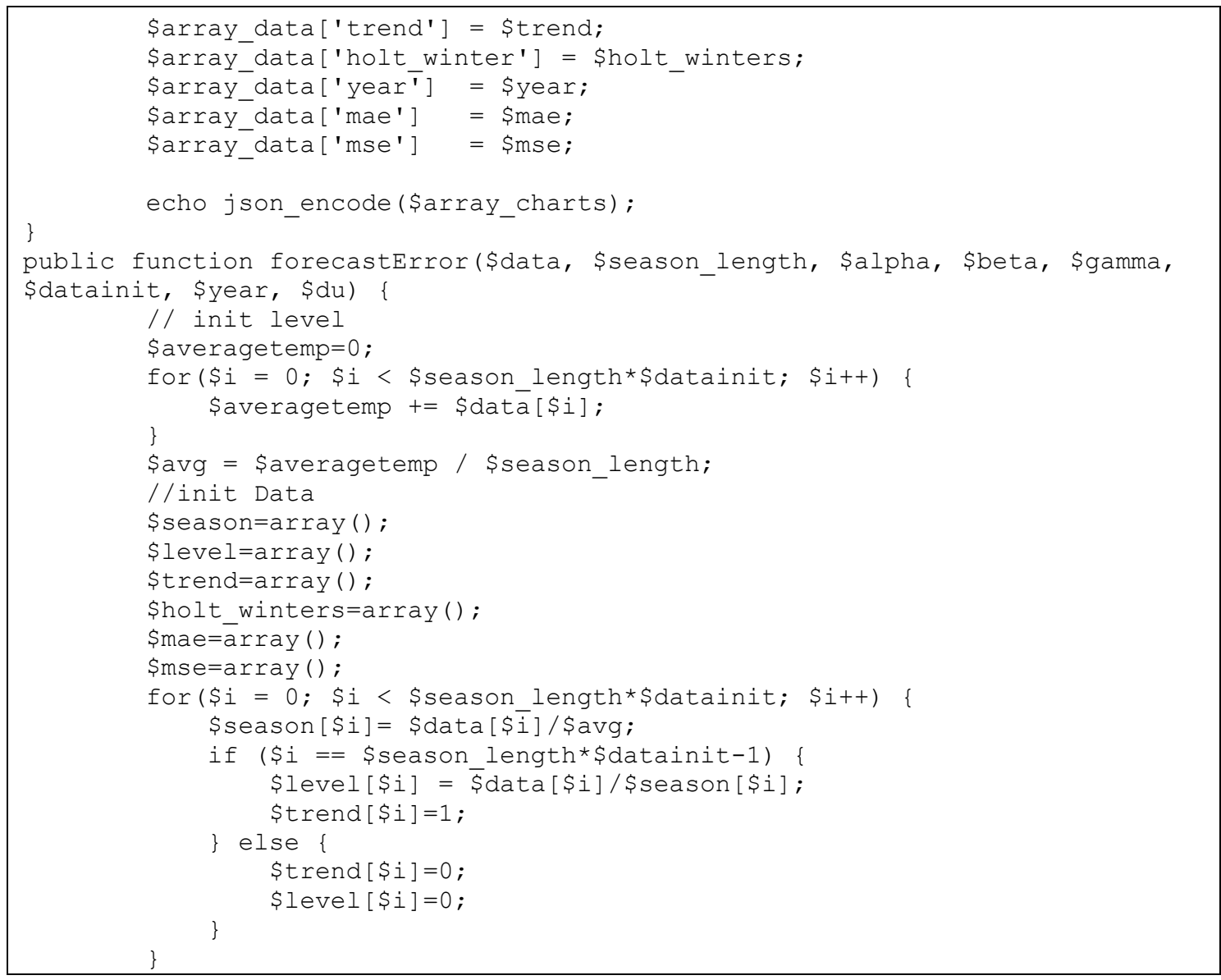

Kode Program 1. Fungsi forcasting Triple Exponential Smoothing

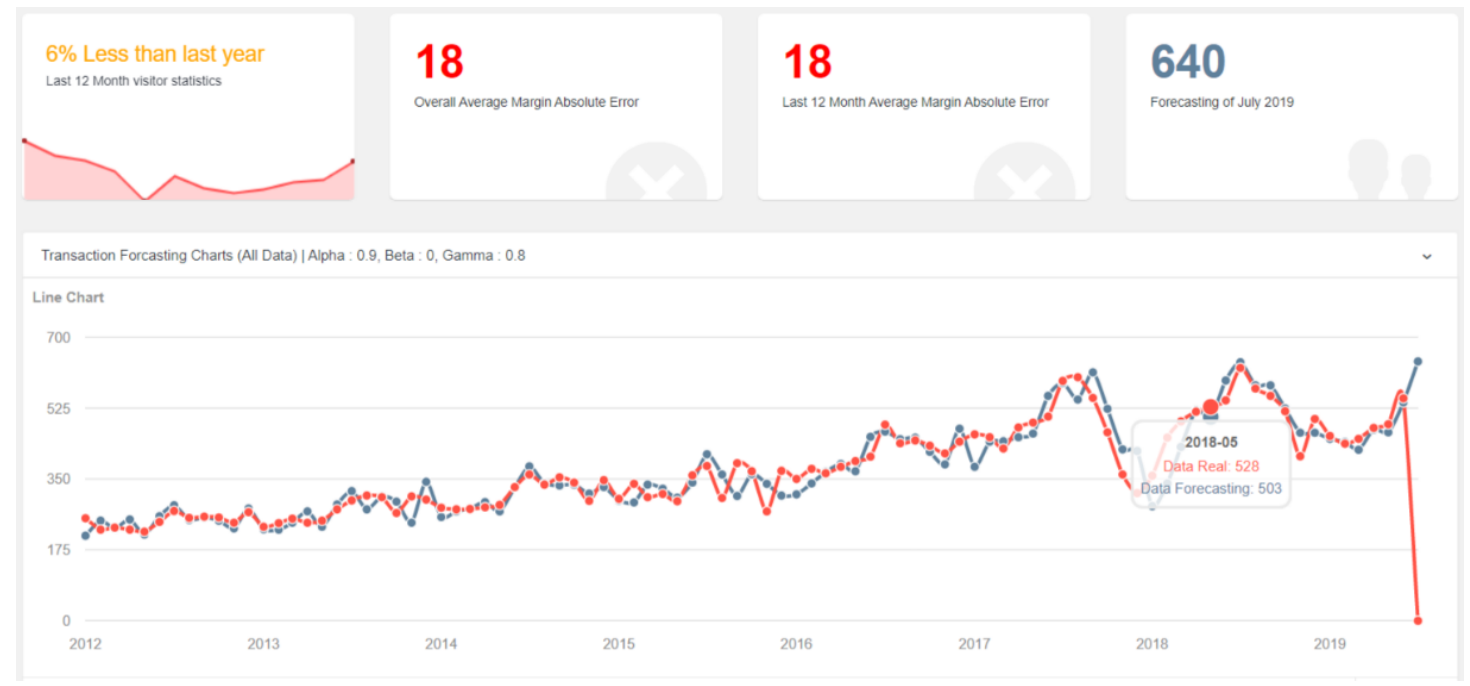

Gambar 3. Grafik hasil peramalan

Gambar 3 merupakan hasil peramalan yang disajikan dalam bentuk grafik perbandingan dataset kunjungan wisatawan dengan hasil peramalan setiap bulannya. Berdasarkan pengamatan terhadap grafik ini, implementasi Triple Exponential Smoothing dapat menghasilkan peramalan kunjungan wisatawan dengan selisih yang kecil dengan dataset kunjungan wisatawan. Hasil peramalan ini selanjutnya akan dievaluasi pada sub bagian evaluasi hasil peramalan untuk mengukur keberhasilan sistem peramalan. 


\subsection{Evaluasi Hasil Peramalan}

Kami melakukan evaluasi pada hasil peramalan dengan mengukur tingkat kesalahan dalam perhitungan peramalan. Evaluasi hasil peramalan dilakukan melalui perhitungan nilai error menggunakan Mean Absolute Error dan Mean Squared Error untuk menunjukan rata-rata kesalahan dalam perhitungan peramalan. Berikut ini adalah kode program yang kami gunakan untuk mengevaluasi hasil peramalan yang ditunjukkan pada Kode Program 1 dan Kode Program 2.

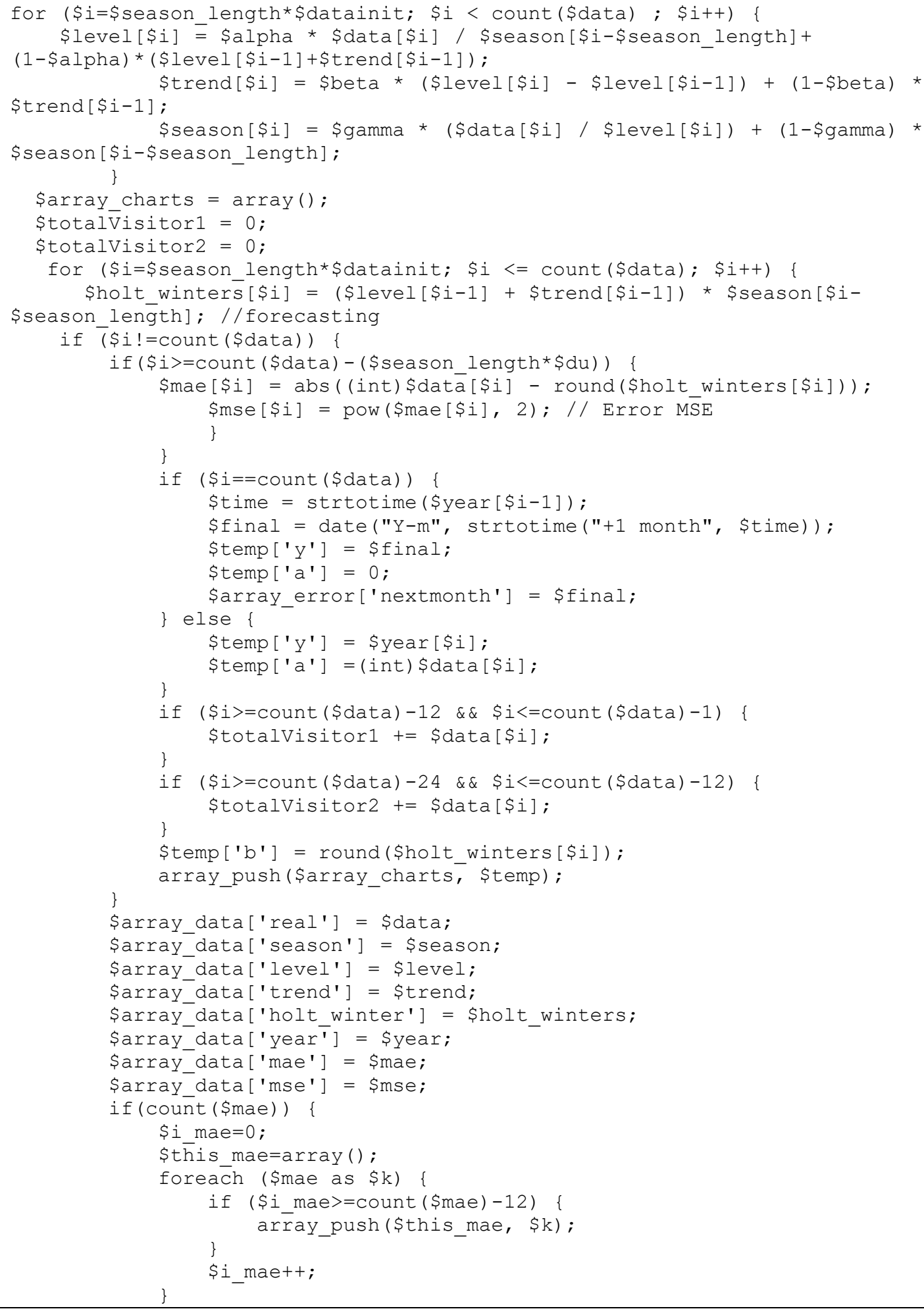




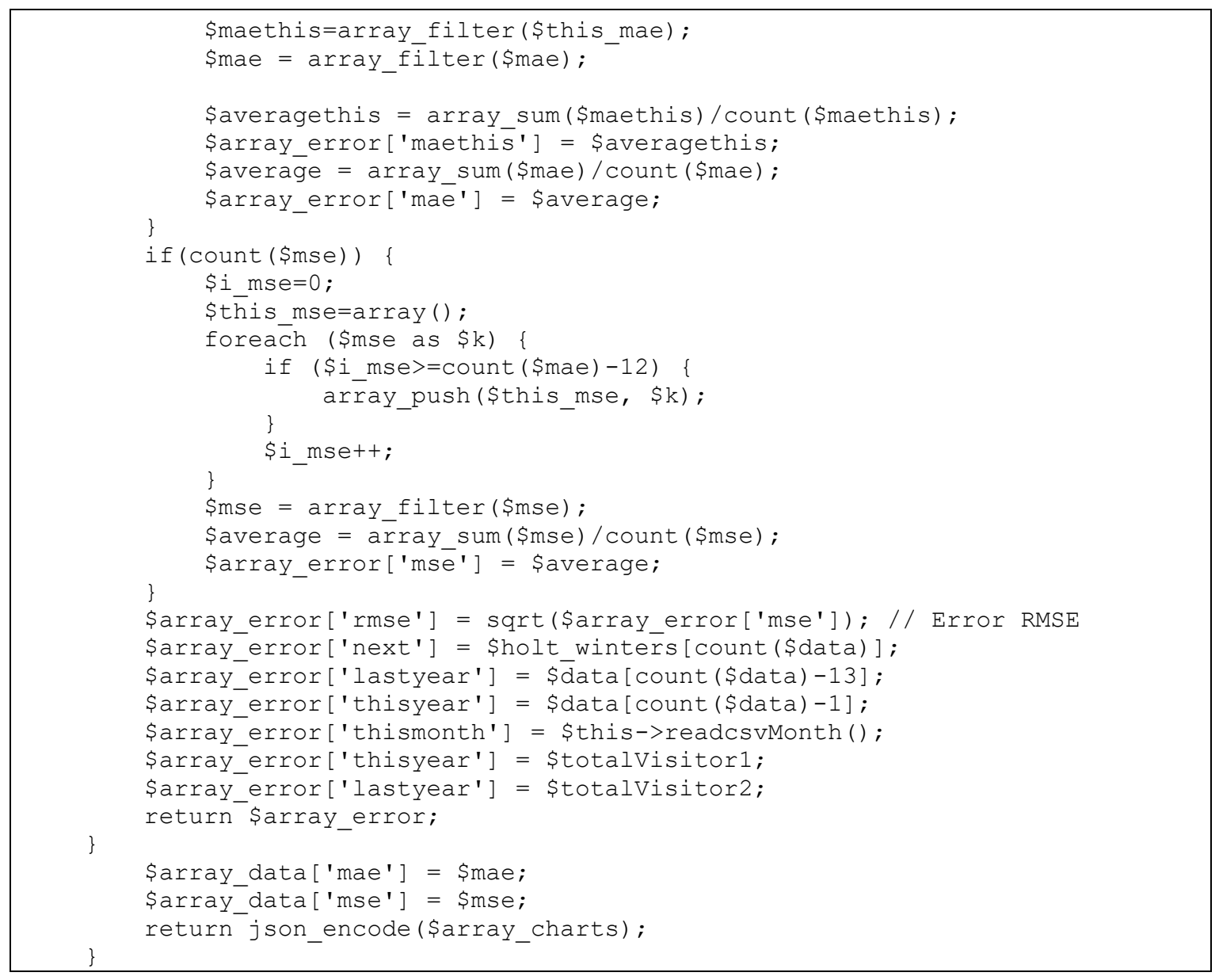

Kode Program 2. Fungsi evaluasi peramalan

Hasil Evaluasi Terbaik

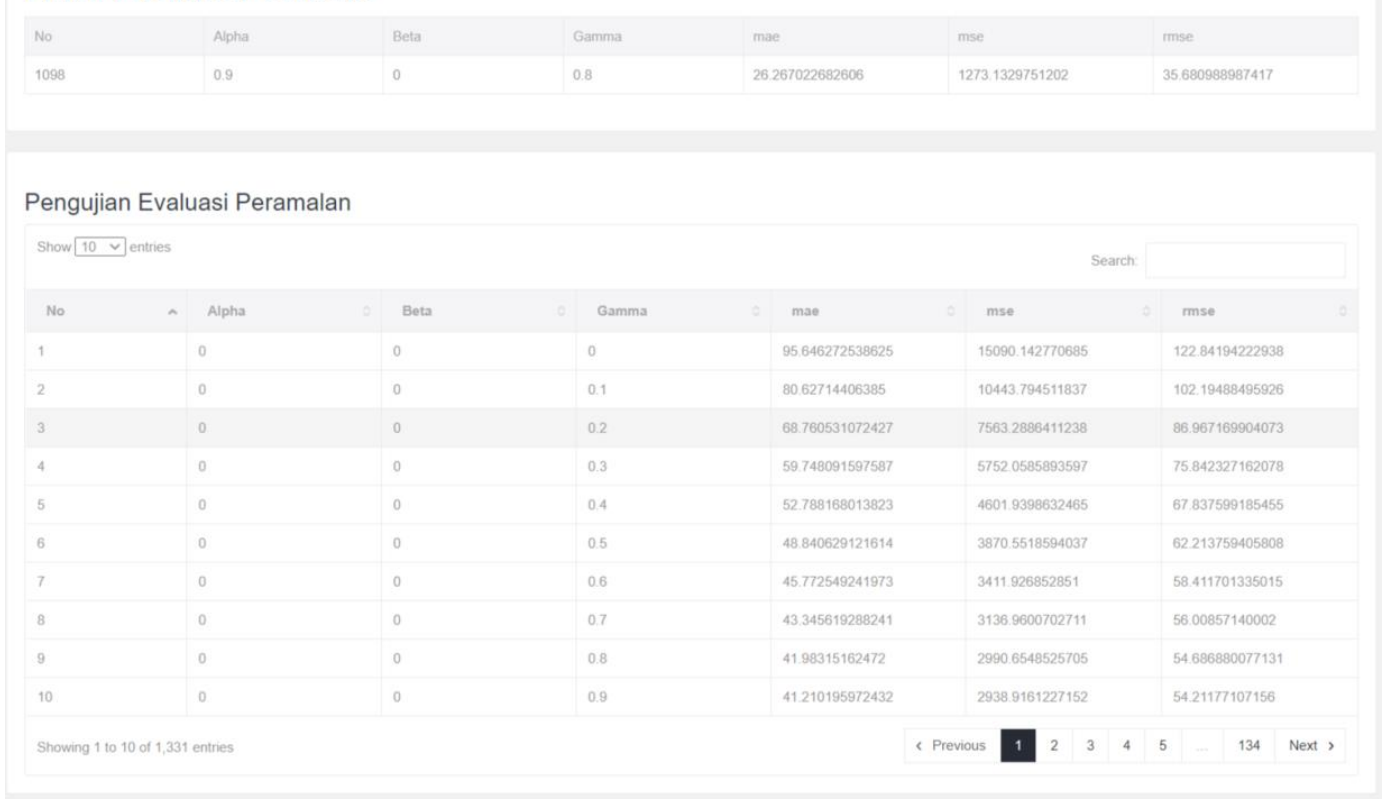

Gambar 4. Evaluasi hasil peramalan 


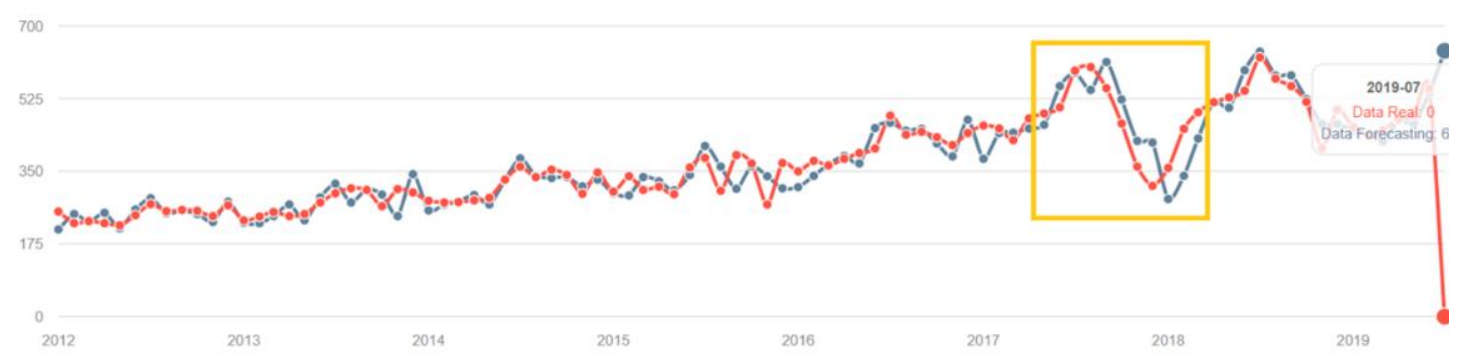

Gambar 5. Penurunan Kunjungan pada Bulan November dan Desember 2017

Gambar 4 merupakan hasil evaluasi peramalan dengan mendapatkan nilai alpha, beta dan gamma terbaik pada proses perhitungan Triple Exponential Smoothing. Nilai alpha, beta dan gamma dihasilkan dengan melakukan perhitungan terhadap kombinasi nilai alpha, beta dan gamma dengan rentang nilai 0 sampai dengan 1 hingga mendapatkan nilai terbaik. Kombinasi terbaik adalah kombinasi yang menghasilkan nilai mean absolute error, mean squared error dan root mean squared error terkecil. Berdasarkan data kunjungan wisatawan ke Bali yang dirilis oleh Badan Pusat Statistik Provinsi Bali, jumlah kunjungan meningkat pada bulan Juli. Hal ini merupakan trend musiman dimana terdapat peningkatan jumlah kunjungan wisatawan ke Bali. Wisatawan mancanegara yang tengah liburan musim panas di negaranya, melakukan liburan ke Bali pada bulan Juli. Berdasarkan data kunjungan wisatawan dengan rentang waktu bulan Januari 2011 sampai dengan bulan Juni 2019, dilakukan pengujian dengan melakukan perhitungan peramalan dengan Triple Exponential Smoothing. Rata-rata mean absolute error yang dihasilkan pada peramalan ini adalah 18 dengan hasil evaluasi terbaik dengan menggunakan Alpha 0.9, Beta 0 dan Gamma 0.8.

Hasil peramalan kunjungan wisatawan juga dipengaruhi oleh faktor situasi yang sedang terjadi di Bali. Jika diperhatikan pada data kunjungan wisatawan ke Bali, terdapat penurunan kunjungan pada bulan November 2017 sebanyak 361,006 dan Desember 2017 sebanyak 315,909 yang ditunjukkan pada Gambar 5. Pada bulan November dan Desember 2017 terjadi penurunan jumlah kunjungan dikarenakan ditetapkannya gunung Agung dengan tingkat siaga pada level tertinggi. Hal ini menjadi salah satu faktor yang menyebabkan hasil peramalan pada bulan tersebut terpaut hingga 100.000 wisatawan dengan data aktual. Faktor pandemi COVID-19 yang terjadi mulai Desember 2019 juga merupakan faktor yang mempengaruhi hasil peramalan, sehingga untuk meningkatkan hasil peramalan masih dibutuhkan penambahan faktor penentu pada perhitungan peramalan.

\section{Kesimpulan}

Penerapan metode Triple Exponential Smoothing sebagai metode peramalan mampu digunakan untuk memprediksi jumlah kunjungan wisatawan berdasarkan data time series. Berdasarkan data kunjungan wisatawan dengan rentang waktu bulan Januari 2011 sampai dengan bulan Juni 2019, dilakukan pengujian dengan melakukan perhitungan peramalan dengan Triple Exponential Smoothing. Rata-rata mean absolute error yang dihasilkan pada peramalan ini adalah 18 dengan hasil evaluasi terbaik dengan menggunakan Alpha 0.9, Beta 0 dan Gamma 0.8. Jika diperhatikan pada data kunjungan wisatawan ke Bali, terdapat penurunan kunjungan wisatawan pada bulan November 2017 sebanyak 361,006 dan Desember 2017 sebanyak 315,909. Pada bulan November dan Desember 2017 terjadi penurunan jumlah kunjungan dikarenakan ditetapkannya gunung Agung dengan tingkat siaga pada level tertinggi. Analisis lebih lanjut mengenai faktor yang mempengaruhi hasil peralaman dibutuhkan untuk meningkatkan hasil peramalan kunjungan wisatawan.

Penelitian selanjutnya yang dapat dilakukan adalah dengan menerapkan metode berbasis deep learning untuk menghasilkan peramalan yang lebih akurat. Pengembangan selanjutnya juga dapat dilakukan dengan menerapkan metode optimasi seperti Particle Swarm Optimization atau metode optimasi lainnya pada penentuan nilai terbaik alpha, beta dan gamma. Penambahan faktor penentu kondisi pariwisata di Bali juga dibutuhkan pada proses perhitungan seperti kondisi Gunung Agung yang sebelumnya mempengaruhi kunjungan 
wisatawan dan pandemi COVID-19 yang saat ini sedang terjadi, karena menjadi faktor yang akan mempengaruhi hasil peramalan kunjungan wisatawan ke Bali.

\section{Ucapan Terima Kasih}

Penelitian ini didanai oleh LPPM STMIK STIKOM Indonesia melalui skema Penelitian dan Pengembangan Dosen STIKI dengan nomor hibah 31/09/LPPM/PPDS//VII/2019.

\section{Daftar Pustaka}

[1] F. Andrian, S. Martha, and S. Rahmayuda, "Sistem Peramalan Jumlah Mahasiswa Baru Menggunakan Metode Triple Exponential Smoothing," Coding: Jurnal Komputer dan Aplikasi, vol. 08, no. 01, pp. 112-121, 2020.

[2] V. A. Fitria and R. Hartono, "Peramalan Jumlah Penumpang Pada Siluet Tour And Travel Kota Malang Menggunakan Metode Triple Exponential Smoothing," Jurnal IImiah Teknologi Informasi Asia, vol. 11, no. 1, pp. 15-20, 2017.

[3] D. Kusuma, M. Rifai, and M. Sudirman, "Penerapan Metode Triple Exponential Smoothing Pada Sistem Prediksi Keuntungan Bisnis Ayam Broiler Guna Meningkatkan Pengelolaan Keuangan Peternak," KILAT, vol. 8, no. 2, pp. 103-111, 2019.

[4] R. Utami and S. Atmojo, "Perbandingan Metode Holt Eksponential Smoothing dan Winter Eksponential Smoothing Untuk Peramalan Penjualan Souvenir," Jurnal IImiah Teknologi Informasi Asia, vol. 11, no. 2, p. 123, 2017.

[5] T. Aprilianto and I. Fauzi, "Perancangan Sistem Peramalan Penjualan Barang Pada UD Achmad Jaya Dengan Metode Triple Exponential Smoothing," Jurnal IImiah Teknologi Informasi (JITIKA), vol. 10, no. 2, pp. 73-86, 2016.

[6] E. S. Astuti, P. P. Arhandi, and P. Lestari, "Pengembangan Sistem Informasi Peramalan Penjualan Guna Menentukan Kebutuhan Bahan Baku Pupuk Menggunakan Metode Triple Exponential Smoothing," Jurnal Informatika Polinema, vol. 4, no. 1, pp. 35-42, 2017.

[7] I. P. A. P. Wibawa, I. K. A. Purnawan, D. P. S. Putri, and N. K. D. Rustajayanthi, "Prediksi Partisipasi Pemilih dalam Pemilu Presiden 2014 dengan Metode Support Vector Machine," Jurnal Ilmiah Merpati (Menara Penelitian Akademika Teknologi Informasi), vol. 7, no. 3, pp. 182-192, 2019.

[8] P. G. Pratiwi, D. Putra, and D. P. S. Putri, "Peramalan Jumlah Tersangka Penyalahgunaan Narkoba Menggunakan Metode Multilayer Perceptron," Jurnal IImiah Merpati (Menara Penelitian Akademika Teknologi Informasi), vol. 7, no. 2, p. 143, 2019.

[9] I. P. S. Putra, D. Putra, and N. Piarsa, "Aplikasi Peramalan Watak dan Perjodohan Berdasarkan Wariga Bali Berbasis Android dengan Metode Fuzzy Logic," Jurnal IImiah Merpati (Menara Penelitian Akademika Teknologi Informasi), vol. 2, no. 3, pp. 380-391, 2016.

[10] I. N. Purnama and A. A. A. P. Ardyanti, "Peramalan Kunjungan Wisatawan Di Obyek Wisata Bedugul Menggunakan Algoritma Fuzzy Time Series," SMARTICS Journal, vol. 3, no. 2, pp. 55-58, 2017.

[11] Masrudin, N. Satyahadewi, and N. Imro'ah, "Peramalan Jumlah Wisatawan Mancanegara Di Kota Pontianak Dengan Metode Seasonalized," Buletin IImiah Mat. Stat. dan Terapannya (BIMASTER), vol. 07, no. 3, pp. 159-168, 2018.

[12] S. Hayoto, Y. A. Lesnussa, H. W. M. Patty, and R. J. Djami, "Peramalan Jumlah Penumpang Pesawat Terbang Di Pintu Kedatangan Bandar Udara Internasional Pattimura Ambon Dengan Menggunakan Metode Arima Box-Jenkins," BAREKENG Jurnal IImu Matematika dan Terapannya, vol. 13, no. 3, pp. 135-144, 2019.

[13] I. Andalita and Irhamah, "Peramalan Jumlah Penumpang Kereta Api Kelas Ekonomi Kertajaya Menggunakan ARIMA dan ANFIS," Jurnal Sains Dan Seni ITS, vol. 4, no. 2, pp. 2-7, 2015.

[14] D. Nur et al., "Sistem Peramalan Penjualan Menggunakan Metode Trend Moment Pada Toko Mebel Nabila Furniture Paguyangan Brebes Berbasis Desktop," Jurnal Informatika UPGRIS, vol. 5, no. 2, pp. 2-6, 2019.

[15] M. R. Putramawan, N. A. Mardiyah, and M. Irfan, "Sistem Peramalan Jumlah Persediaan Minuman Menggunakan Metode Moving Average," CYCLOTRON, vol. 2, no. 1, pp. 20-23, 2019. 
[16] M. R. Djalal and F. Faisal, "Intelligent Fuzzy Logic - Cuckoo Search Algorithm Method for Short-Term Electric Load Forecasting in 150 kV Sulselrabar System," Lontar Komputer: Jurnal IImiah Teknologi Informasi, vol. 8, no. 3, p. 154, 2017.

[17] R. R. Waliyansyah and N. D. Saputro, "Forecasting New Student Candidates Using the Random Forest Method," Lontar Komputer: Jurnal IImiah Teknologi Informasi, vol. 11, no. 1, p. 44, 2020. 